\title{
Herbivory and community organization on a subtidal cobble bed
}

\author{
Robert E. Scheibling ${ }^{1, *}$, Noreen E. Kelly ${ }^{1,2}$, Bruce G. Raymond ${ }^{1,3}$ \\ ${ }^{1}$ Biology Department, Dalhousie University, Halifax, Nova Scotia B3H 4J1, Canada \\ ${ }^{2}$ Present address: Centre for Marine Biodiversity, Biological Station, 531 Brandy Cove Road, St. Andrews, \\ New Brunswick E5B 2L9, Canada \\ ${ }^{3}$ Present address: Environment, Energy and Forestry, 11 Kent Street, PO Box 2000, Charlottetown, \\ Prince Edward Island C1A 7N8, Canada
}

\begin{abstract}
We examined the role of molluscan mesograzers (periwinkles Littorina littorea, limpets Testudinalia testudinalis and chitons Ischnochiton ruber) in mediating macroalgal succession after a mass mortality of sea urchins Strongylocentrotus droebachiensis in a subtidal cobble bed in Nova Scotia, Canada. Experimental exclusions of mesograzers from cobbles encrusted with smooth (Phymatolithon) or rugose (Lithothamnion) coralline algae resulted in the establishment of a variety of ephemeral filamentous algae, suggesting that these small ( 2 to $5 \mathrm{~mm}$ ) but abundant herbivores are the dominant agents controlling early succession and community organization in this habitat. In removing inhibitive effects of early successional species, molluscan grazing facilitated the establishment of fleshy perennial species Fucus evanescens and Chondrus crispus, which occasionally escaped grazing at small size to attain a growth refuge on the cobbles. Algal biomass and species richness were greater on Lithothamnion than Phymatolithon, suggesting that rugose crusts provide more favourable microhabitats for recruitment or survival of various macroalgae. The distribution of mesograzers differed between coralline types, likely influencing the rate and intensity of grazing: periwinkles foraged on both types of crust, whereas limpets occurred primarily on Phymatolithon and chitons on Lithothamnion. All non-coralline algae were consumed when urchins were experimentally reintroduced to the cobble bed, returning the assemblage to the urchin barrens state.
\end{abstract}

KEY WORDS: Algal community structure · Encrusting coralline algae • Biological disturbance . Molluscan mesograzers · Rocky subtidal zone $\cdot$ Sea urchins $\cdot$ Spatial complexity $\cdot$ Succession

\section{INTRODUCTION}

Grazing has long been recognized as an important driving force controlling the composition, distribution and succession of benthic communities in intertidal and subtidal habitats (Paine \& Vadas 1969, Ayling 1981, Lubchenco \& Gaines 1981, Witman 1985, Carpenter 1986). In addition to removing algal biomass, grazers can alter competitive interactions among species (Lubchenco 1980, 1983, Dethier \& Duggins 1984) and the rate of community succession (Breitburg 1985, Farrell 1991, Kim 1997, Benedetti-Cecchi 2000) and indirectly affect the recruitment and survival of other species (Underwood et al. 1983, Petraitis 1990, Anderson \& Underwood 1997). Both physical (e.g. wave action, temperature, turbidity) and biological (e.g. predation, disease) factors affect the foraging ability of herbivores, leading to spatial and temporal variation in the frequency and intensity of grazing (Lubchenco \& Gaines 1981). Habitat structural complexity and spatial heterogeneity also affect foraging efficiency and provide refuges for species to escape grazing (Heck \& Wetstone 1977, Menge \& Lubchenco 1981, Lubchenco 1983, Menge et al. 1985, Williams et al. 2000). 
Herbivorous molluscs and sea urchins can have profound effects on the structure of macroalgal assemblages. Dense aggregations (fronts) of urchins destructively graze algal beds, altering habitat structure, diversity and productivity in coastal habitats (Himmelman et al. 1983, Johnson \& Mann 1988, Carpenter 1990, Scheibling et al. 1999, Lauzon-Guay \& Scheibling 2007). Molluscan grazers directly or indirectly alter patterns of distribution and abundance of algae and sessile invertebrates on rocky intertidal shores (Lubchenco \& Gaines 1981, Duggins \& Dethier 1985, Farrell 1988, Jenkins et al. 1999, 2005, BenedettiCecchi et al. 2000, Boaventura et al. 2002, Paine 2002). Less is known about the role of molluscan grazers in subtidal habitats or their interaction with urchins in these areas (Vanderklift \& Kendrick 2004, Russell \& Connell 2005).

The rocky subtidal ecosystem of the Northwest Atlantic is characterized by 2 alternative community states: an unproductive barrens state dominated by the sea urchin Strongylocentrotus droebachiensis and coralline algae, and a highly productive algal bed state dominated by laminarian kelps with low densities of urchins (Johnson \& Mann 1988). Transitions between community states (phase shifts) are driven by biological interactions, with destructive grazing by urchins mediating the transition from kelp beds to barrens, and disease outbreaks that decimate urchin populations enabling the recovery of kelp beds (Scheibling 1986, Lauzon-Guay et al. 2009). Following mass mortalities of urchins, macroalgal recolonization of barrens proceeds from an early successional stage characterized by small, fast-growing species (diatoms and filamentous algae) that are competitively displaced by canopy-forming kelps later in succession (Himmelman et al. 1983, Scheibling 1986, Johnson \& Mann 1988, Scheibling et al. 1999). Exceptions to these alternate community states exist, notably on rocky substrata that are too unstable to allow the growth of large kelps, resulting in an algal assemblage that is dominated by coralline crusts and small turf-forming algae (Davis \& Wilce 1987 Scheibling \& Raymond 1990).

In the early 1980 s, a shift from the barrens to the kelp bed state occurred along the Atlantic coast of Nova Scotia, Canada, following recurrent outbreaks of disease that effectively eliminated Strongylocentrotus droebachiensis from the shallow $(<20 \mathrm{~m})$ subtidal zone (Miller 1985, Scheibling 1986). Scheibling \& Raymond (1990) monitored this transition in a cobble bed and surrounding boulder field at a site (Eagle Head) in southwestern Nova Scotia between 1982 and 1987. Prior to their mass mortality in 1983, urchins had dominated the macrobenthic community on the cobble bottom, precluding the establishment of non-coralline algae (Scheibling 1984). By 1985, a luxuriant canopy of large kelps and fucoid algae had developed on an adjacent boulder ridge. In contrast, on the cobble bottom, the developing algal assemblage consisted of small $(<5 \mathrm{~cm}$ in length) and sparsely distributed species, mainly Fucus evanescens and Chondrus crispus (Scheibling \& Raymond 1990). The cobbles and their coralline algal crusts provide a structurally complex habitat and food source for a guild of small molluscan grazers. After the mass mortality of sea urchins, these mesograzers $(<2$ to $5 \mathrm{~cm}$ in body length; sensu Brawley 1992) became the dominant functional group in cobble beds at Eagle Head and elsewhere along the Nova Scotian coast (Scheibling \& Raymond 1990). Periwinkles Littorina littorea accounted for most of the grazer biomass, but smaller and more sedentary chitons Ischnochiton ruber and limpets Testudinalia testudinalis were highly abundant on rugose and smooth coralline crusts, respectively (Scheibling \& Raymond 1990).

The natural elimination of urchins presented a rare opportunity to test hypotheses about processes regulating the rate and pattern of colonization and succession of macroalgae and sessile invertebrates in cobble beds, and the relative roles of urchins and molluscan mesograzers in determining the structure of the benthic community (Scheibling \& Raymond 1990). First, we hypothesized that dense populations of periwinkles, limpets and chitons limit colonization and regulate the succession of macroalgae on cobbles in the absence of urchins. We predicted that experimental exclusion of molluscan mesograzers would increase the biomass and diversity of algal colonists on cobbles. This prediction was supported by differences in the pattern of succession on cobbles relative to adjacent boulder fields, where these grazers tend to be less abundant (Scheibling \& Raymond 1990). Second, we hypothesised that herbivory by small molluscs is mediated by the fine-scale spatial complexity of coralline crusts. Rugose crusts such as Lithothamnion may facilitate settlement of algal propagules and invertebrate larvae, and increase post-settlement survival by providing micro-refuges from grazers (Scheibling \& Raymond 1990, Scheibling \& Robinson 2008). Therefore, we predicted that rates of colonization of algae and sessile invertebrates would be higher on rugose than smooth crusts. Third, we hypothesised that seasonal variation in environmental factors and the supply of propagules determines the potential for algal colonization and growth on cobbles, and predicted that the magnitude of herbivore effects would vary over time. Fourth, we hypothesised that dense urchin populations override any regulation by molluscan mesograzers, and predicted that reintroduction of urchins to the cobble bed would rapidly return the algal assemblage to a coralline-dominated barrens 
state. This was based on observations at a site where the urchin population appeared to have recovered shortly after a mass mortality, precluding the establishment of non-coralline algae in a cobble bed (Scheibling \& Raymond 1990). We tested these 4 hypotheses in a series of manipulative experiments at Eagle Head. Our experimental results, and those of a concurrent study of the effects of wave action on cobbles and attached macroalgae (Scheibling et al. 2008), provide insight into the relative roles of biological and physical disturbance in cobble beds, and enable comparisons with processes regulating community structure and dynamics on stable rocky substrata, such as boulder fields and bedrock ledges.

\section{MATERIALS AND METHODS}

Study site and benthic community. The cobble bed at Eagle Head, Nova Scotia, Canada $\left(44^{\circ} 04^{\prime} \mathrm{N}\right.$, $64^{\circ} 36^{\prime} \mathrm{W}$ ) lies in a shallow ( 2 to $3 \mathrm{~m}$ below mean low water) nearshore basin $\left(\sim 5000 \mathrm{~m}^{2}\right)$ bounded by a submerged boulder ridge along its offshore extent. The site is exposed to oceanic swells from the southeast, although the ridge dissipates much of the incoming wave energy. Strong onshore winds and heavy seas are most frequent in winter. Bottom water temperature varies seasonally from 1 to $18^{\circ} \mathrm{C}$ but salinity is relatively constant around 31 . The cobbles are composed of greywacke and heavily encrusted with coralline red algae of the genera Lithothamnion, Clathromorphum and Phymatolithon. A closely packed upper layer of cobbles overlies deeper strata with dead coralline crusts and sediment. Mean cobble length is $7 \mathrm{~cm}$, bordering on pebble classification on the Wentworth (1922) scale; mean dry mass is $164 \mathrm{~g}$. For a detailed description of the site and benthic community, see Scheibling \& Raymond (1990).

Manipulative experiments with cobbles. We examined the effect of molluscan mesograzers (periwinkles, limpets and chitons) and type of coralline crust on colonization and succession of macroalgae and sessile or sedentary invertebrates in 3 field experiments. Cobbles used in these experiments were carefully selected from the natural bed for uniformity in size $(6$ to $7 \mathrm{~cm}$ length), shape (roughly ellipsoidal) and coralline algal cover ( $>95 \%$ on the upper surface). The corallines were of 2 distinct morphological types: Lithothamnion glaciale (hereafter Lithothamnion) is a rugose crust with short nubbly branches; Phymatolithon laevigatum and $P$. rugulosum (hereafter Phymatolithon) are smooth crusts (the 2 species were not readily distinguishable in the field). Selected cobbles were devoid of other macroalgae. Small mussels, amphipod tubes, polychaetes and algal germlings occasionally were found on Lithothamnion and removed for all treatments. For grazer exclusion treatments (see below) cobbles were carefully scrutinized and all small chitons and limpets were removed. Five cobbles of each coralline type were regularly spaced in an alternating pattern on a $39 \times 19 \times 4 \mathrm{~cm}$ cement platform (building block) and attached with fast-drying cement (Quick Plug, Bondex International). In preliminary laboratory tests, we found no evidence of a toxic effect of this cement on local algae or invertebrates. Completed platforms were placed in a sheltered subtidal area to allow the cement to cure, and then transported underwater to the experimental site within 2 to $4 \mathrm{~h}$.

In Expt 1, we examined the cumulative effects of grazers and coralline cover on the colonization of cobbles measured at 3 mo (seasonal) intervals over $1 \mathrm{yr}$ (1985-1986): (1) fall, 22 August to 19 November; (2) winter, 20 November to 25 February; (3) spring, 26 February to 19 May; and (4) summer, 20 May to 27 August. Grazers were excluded by raising the experimental platform $9 \mathrm{~cm}$ off the bottom on 4 stilts $(5 \mathrm{~mm}$ diameter, threaded stainless steel rod) anchored in a large cement building block that was buried in the cobble bottom (Stilts, Fig. 1a). Plastic jar lids (60 mm diameter), filled with a sticky gum (Tree Tanglefoot Paste, Tanglefoot), capped each of the stilts (with gum side down) as a potential barrier to any grazers capable of climbing the stilts. In the grazer control treatment, grazers were allowed access to experimental cobbles by placing the platform flush with the surface layer of cobble (Flush, Fig. 1b). In a procedural control for potential elevation effects (e.g. alteration of hydrodynamic conditions influencing settlement of propagules, reduction of abrasion from surrounding cobble or macroalgae, reduction of shading), the platform was placed on a solid concrete block at the same height as the platform on stilts (Block, Fig. 1c). This also allowed access to grazers, which readily climbed up the block and onto the cobble. To compensate for dislodgement of grazers during handling of cobble and experimental platforms, 3 each of chitons Ischnochiton ruber and limpets Testudinalia testudinalis were placed on each Lithothamnion and Phymatolithon cobble, respectively, in the Block treatment, in accordance with the natural occurrence of these grazers on both coralline types at Eagle Head (Table 1). There were 4 replicates of each combination of 3 grazer treatments (Stilts, grazer exclusion; Flush, grazer access; Block, grazer access and elevation control), 2 coralline types (Lithothamnion and Phymatolithon, on each experimental unit) and 4 sampling times (3, 6, 9 and 12 mo). These replicates were allocated in a randomized complete block design to 48 positions spaced at $1 \mathrm{~m}$ intervals in a linear layout. Twelve experimental units (4 replicates of each grazer $\times$ coralline treatment) were sampled at each time. 

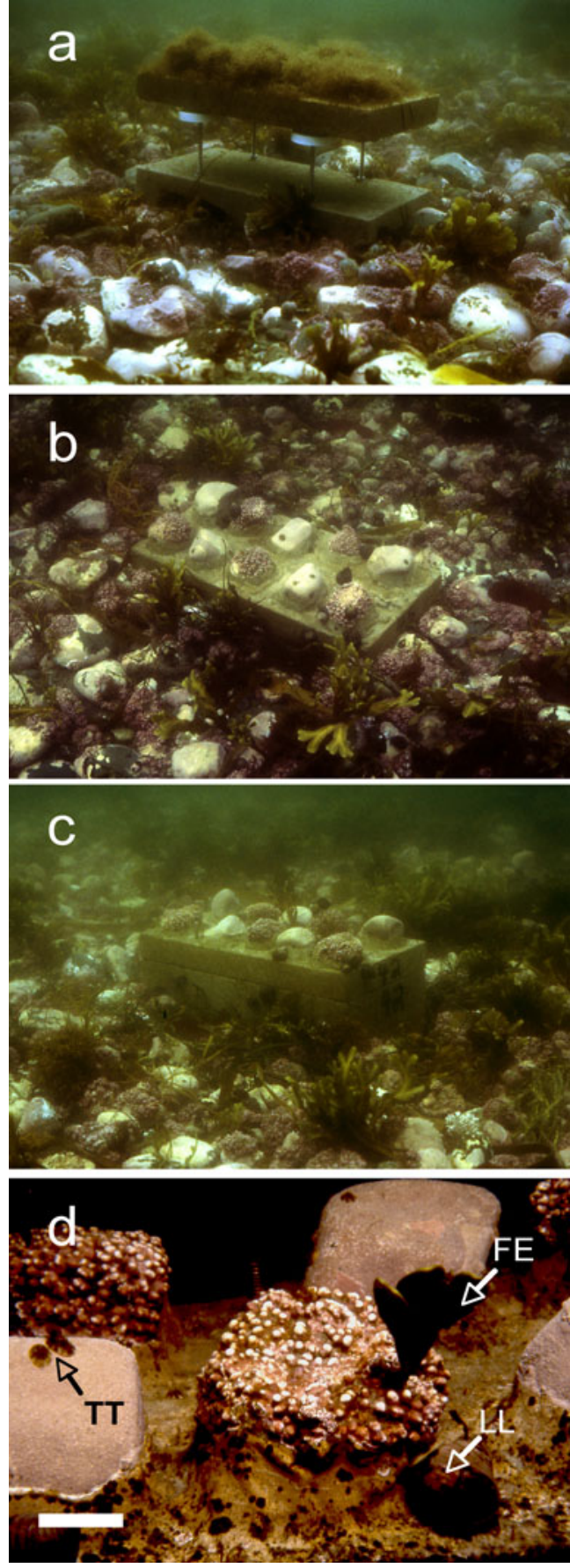

Fig. 1. (a) Stilts (grazer exclusion) unit, (b) Flush (grazer access) unit and (c) Block (grazer access and procedural control) unit in Expt 1 (note the dense overgrowth of filamentous red algae on cobbles on the Stilts unit in contrast to cobbles on the Block and Flush units that are intensively grazed by periwinkles, limpets and chitons). (d) Juvenile Fucus evanescens (FE) growing on Lithothamnion on a Block unit (grazer access and procedural control) in Expt 1, and the manipulated mesograzers Littorina littorea (LL) and Testudinalia testudinalis (TT). Photographs $(\mathrm{a}-\mathrm{c})$ were taken on 10 October 1985; the length of the experimental platform (cement block) is $39 \mathrm{~cm}$. Photograph (d) was taken in February 1986; scale bar $=2 \mathrm{~cm}$
Table 1. Testudinalia testudinalis and Ischnochiton ruber. Numbers of limpets and chitons on cobbles encrusted (>95\% cover) with Lithothamnion or Phymatolithon. Data are means \pm SD (ind. cobble ${ }^{-1}$ ) for samples from the cobble bed at Eagle Head, Nova Scotia, Canada in August 1985

\begin{tabular}{|lccc|}
\hline $\begin{array}{l}\text { Coralline } \\
\text { type }\end{array}$ & $\begin{array}{c}\text { No. of } \\
\text { cobbles }\end{array}$ & $\begin{array}{c}\text { Testudinalia } \\
\text { testudinalis }\end{array}$ & $\begin{array}{c}\text { Ischnochiton } \\
\text { ruber }\end{array}$ \\
\hline $\begin{array}{l}\text { Lithothamnion } \\
\text { Phymatolithon }\end{array}$ & 96 & $0.1 \pm 0.2$ & $2.6 \pm 2.3$ \\
\hline
\end{tabular}

Expt 2 was run concurrently with Expt 1 and set up similarly, but here we examined seasonal differences in colonization of cobble (rather than cumulative effects). A new series of 12 experimental units (4 replicates of each grazer $\times$ coralline treatment) was set out in each season for 4 successive 3 mo intervals. Thus, the first series of 12 units sampled in Expt 1 (at 3 mo) also served as the first series in Expt 2, and those of subsequent series were placed in the same positions in the experimental layout.

In Expts 1 and 2, platforms were monitored at 2 to $4 \mathrm{wk}$ intervals to ensure the efficacy of the grazer manipulation and maintain a qualitative record of algal colonization patterns. On termination of an experiment (or a treatment series) cobbles were removed from platforms with a hammer and chisel. This was done from a boat on site and each cobble was immediately placed in a separate labelled plastic bag. The cobble samples were transported in coolers to the laboratory and frozen until processed. They were then thawed in seawater and macroalgae and invertebrates were removed and sorted by species. Fleshy macroalgae (e.g. Chondrus crispus, Fucus evanescens, kelps) and invertebrates were counted and measured (shell length for molluscs, frond length for algae; $1 \mathrm{~mm}$ accuracy). Macroalgal species were blotted and then oven dried at $80^{\circ} \mathrm{C}$ for $48 \mathrm{~h}$ and weighed (1 $\mathrm{mg}$ accuracy). When the dry mass of an alga was $<1 \mathrm{mg}$ it was assigned an arbitrary mass of $0.5 \mathrm{mg}$ to record its presence. Macroalgal biomass was recorded per exposed surface area of cobble as mg $10 \mathrm{~cm}^{-2}$ $\left(=\mathrm{g} \mathrm{m}^{-2}\right)$, which was measured using a surface-film technique (Scheibling \& Raymond 1990). The mean surface area of individual cobbles (for all cobbles in Expts 1 and 2) was 48 and $53 \mathrm{~cm}^{2}$ for Lithothamnion and Phymatolithon cobbles, respectively, and did not differ significantly between coralline types ( $t$-test, $\mathrm{p}>0.15)$.

For statistical analysis, the 5 cobbles of each coralline type on a platform were treated as subsamples and averaged to measure biomass of algae or density of invertebrates per replicate. On 2 platforms in Expt 1, a single cobble of one or both coralline types was dislodged, and means were calculated from the remaining 4 cobbles. Data were $\log (x+1)$-transformed to minimize heteroscedasticity (assessed using Bartlett's test) and 
analyzed by factorial ANOVA of a split-plot design. In Expts 1 and 2, grazer treatment (3 levels: grazer exclusion and 2 controls) and sampling period (4 levels: cumulative or successive 3 mo intervals) were orthogonal, main-plot factors in a randomized complete block design. Coralline type was the sub-plot factor (2 levels: Lithothamnion, Phymatolithon) within each main plot. The systematic alternation of subsamples (individual cobbles) of each coralline type represents a modification of the standard split-plot design (in which each coralline type would be randomly assigned to one half of a main plot). Systematic interspersion of subsamples of each of the 2 levels of the sub-plot factor should be more effective than random allocation in reducing the potential for bias due to small-scale (within plot) variability and/or non-demonic intrusion (sensu Hurlbert 1984). An advantage of the split-plot design is that it allowed us to accommodate a third factor (coralline type) without increasing the number of experimental units, which was set by logistical constraints on sampling time and space. Planned pair-wise comparisons of means were done using a $t$-test to calculate the least significant difference (LSD) at $\alpha=0.05$. Appropriate error terms and weighted $t$-values for different types of comparisons are given in Gomez \& Gomez (1984). Block and Stilts treatments were compared to test for a grazer effect independent of a potential effect of elevation. Flush and Block treatments were compared to test for an elevation effect in the presence of grazers.

For Expts 1 and 2, we calculated algal species richness $(S)$ as the total number of species from replicates pooled within each treatment combination. To compare temporal trends among grazer treatments and coralline type for the algal assemblage as a whole, we used non-metric multidimensional scaling (nMDS) based on Bray-Curtis dissimilarities (Clarke \& Warwick 1994). To construct the dissimilarity matrix, species biomass was 4th-root transformed to increase the weighting of rare species and decrease that of abundant ones. Multivariate analyses were conducted using PRIMER 5 software (Clarke \& Warwick 1994).

In Expt 3, we examined the separate effects of limpets and periwinkles on algal colonization of cobbles over 3 mo (6 September to 6 December 1985). There were 2 replicates each of 3 grazer treatments: (1) Flush, grazer access (control); (2) Stilts, periwinkle exclusion (3 each of chitons and limpets were added to Lithothamnion and Phymatolithon cobbles, respectively); and (3) Stilts, periwinkle and limpet exclusion. (We were unable to successfully exclude chitons from the Stilts treatment, or to exclude limpets while allowing access to periwinkles, which precluded testing the separate effects of each grazer species.) These replicates were randomly allocated to 6 positions (spaced at $1 \mathrm{~m}$ intervals) adjacent to the main experimental layout. Comparisons between grazer exclusion treatments were done using a $t$-test.

Urchin grazing experiment. To examine the effect of grazing by Strongylocentrotus droebachiensis on the established macroalgal community of the cobble bed, we enclosed urchins in 3 bottomless cages (1 m diameter, $40 \mathrm{~cm}$ height, $16 \mathrm{~mm}$ mesh aperture) placed over the cobble and guyed to cement anchor blocks. Another 3 cages of the same design but without urchins provided a procedural control for possible cage effects, and 3 circular plots (1 m diameter) provided an unmanipulated control. Replicates of each of the 3 treatments were randomly allocated to 9 plots (6 caged, 3 unmanipulated) spaced at $5 \mathrm{~m}$ intervals on the cobble bottom at $3 \mathrm{~m}$ depth. At the time, urchins were virtually absent on the cobble bed. They occurred under rocks on the adjacent boulder ridge but were small (<30 mm diameter) and cryptic (Scheibling \& Raymond 1990). Therefore, larger specimens (40 to $50 \mathrm{~mm}$ ) were imported for the experiment from a population in the Bay of Fundy (Sandy Cove, Nova Scotia; 44⒉ $9^{\prime} \mathrm{N}, 6^{\circ} 06^{\prime} \mathrm{W}$ ), and 30 ind. were placed in each of the 3 replicate cages for that treatment. This closely matched the body size and density of the urchins that inhabited the cobble bottom before the mass mortality (Scheibling \& Stephenson 1984).

After 3 mo (15 July to 23 September 1986), the substratum within each experimental plot was photographed (without cages in place) from a point $3 \mathrm{~m}$ directly over the center. We estimated the percentage cover of the fleshy algae by superimposing 50 random points on photographic images of each plot and scoring the number of points falling on algae. All cobbles with attached macroalgae were collected within each plot and placed in separate plastic bags. In the laboratory, macroalgae were removed from the cobbles and dry mass of each species was measured as described above.

One-way ANOVA was applied to measures of percentage cover and biomass after arcsin and log transformation, respectively (Bartlett's test on transformed data, $\mathrm{p}>0.10)$. Planned pair-wise comparisons of means (LSD at $\alpha=0.05$ ) contrasted urchin cages vs. control cages (without urchins) to test for grazing effects, and control cages vs. unmanipulated plots to test for potential cage effects.

\section{RESULTS}

\section{Efficacy of mesograzer manipulation}

Expts 1 and 2 were sampled concurrently and patterns in the distribution and abundance of grazers among treatments were similar between experiments 
(Figs. 2, $3 \& 4$ ). The Stilts treatment was highly effective in excluding grazers: periwinkles Littorina littorea were absent (Fig. 2) and limpets Testudinalia testudinalis were rare at all sampling periods (Fig. 3). Infrequently, 1 or 2 periwinkles were found on a stilted platform during routine maintenance surveys and removed. These may have arrived via large fragments of drift kelp that occasionally lodged against the stilts; none was observed climbing the stilts. A few chitons Ischnochiton ruber were found on Lithothamnion in the stilted treatment at all sampling periods (mean density never exceeded 2 cobble $^{-1}$, Fig. 4). Chitons are highly cryptic and some probably were missed when exclusion treatments were set up. Others presumably settled on Lithothamnion as planktonic larvae, particularly during the fall when recruitment occurred in the natural population (Scheibling \& Raymond 1990). Recently settled chitons ( $<2 \mathrm{~mm}$ shell length) were most abundant in the Stilts treatment in November 1985 (15\% of individuals).
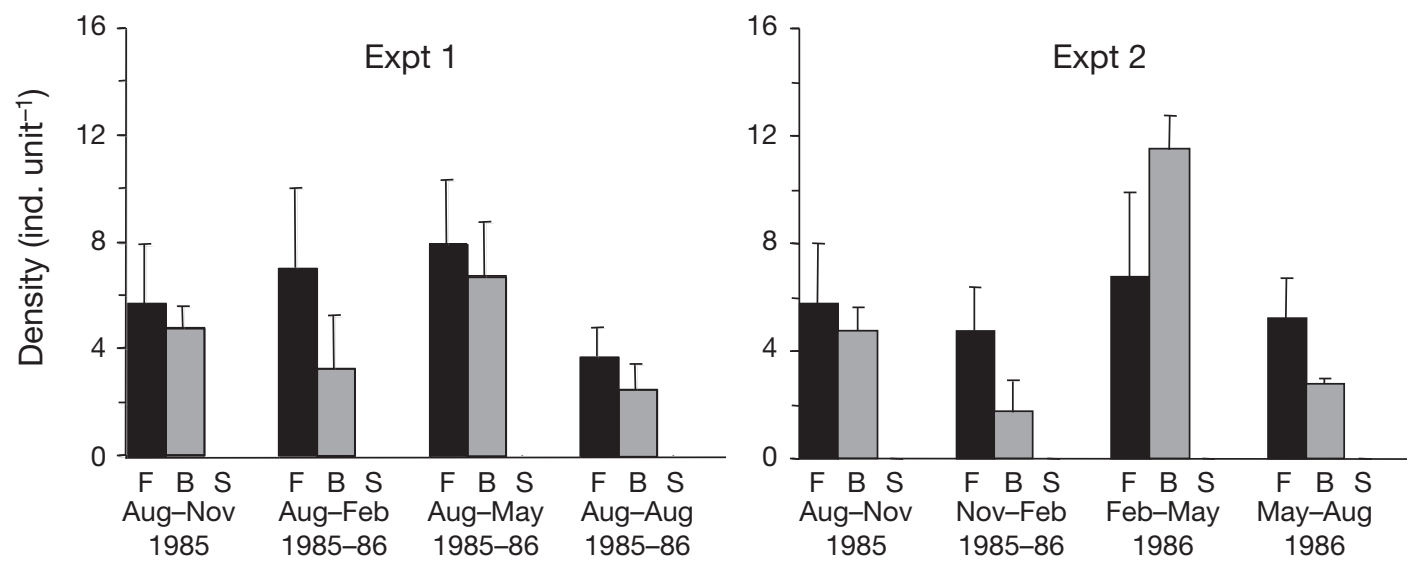

Treatment and period

Fig. 2. Littorina littorea. Mean $(+\mathrm{SE}, \mathrm{n}=4)$ density of perwinkles on experimental units (platform with affixed cobbles) in each of 3 grazing treatments (F: Flush, grazer access; B: Block, grazer access and procedural control; S: Stilts, grazer exclusion) at 4 time periods in Expts 1 and 2

Expt 1

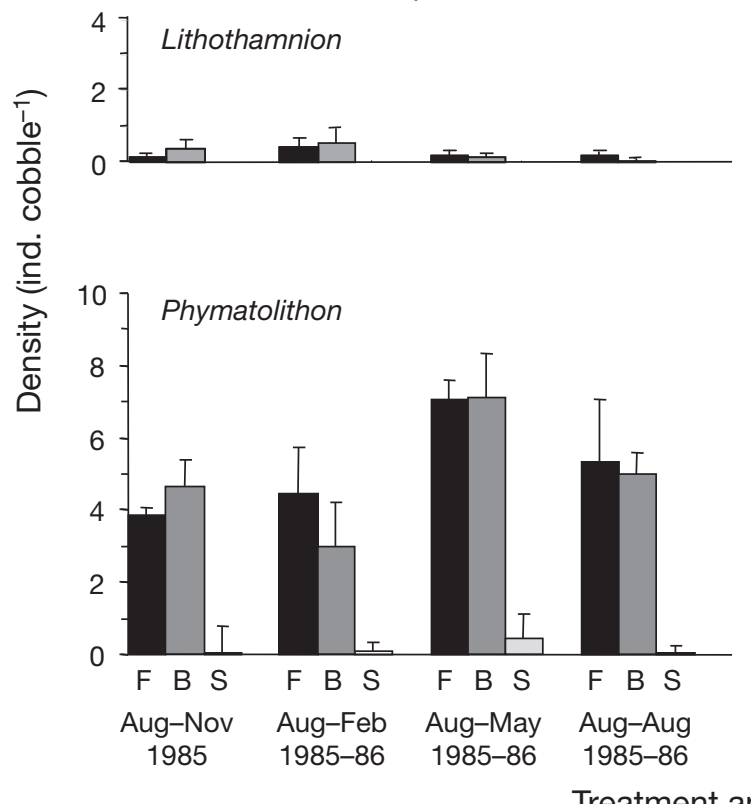

Expt 2
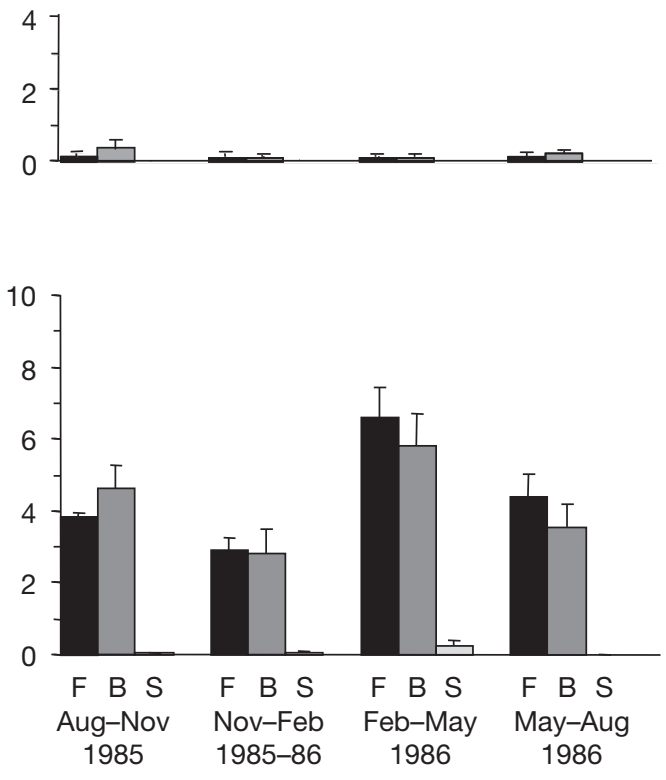

Fig. 3. Testudinalia testudinalis. Mean $(+\mathrm{SE}, \mathrm{n}=4)$ density of limpets on experimental cobbles encrusted with Lithothamnion or Phymatolithon in each of 3 grazing treatments (F: Flush, grazer access; B: Block, grazer access and procedural control; S: Stilts, grazer exclusion) at 4 time periods in Expts 1 and 2 
All 3 grazer species consistently occurred on cobbles in the Flush and Block treatments in both experiments (Figs. 2, 3 \& 4). Density of each species did not differ significantly $(p>0.05)$ between Flush and Block treatments at each sampling period in both experiments, with one exception (chitons: Expt 2, Lithothamnion, February to May 1986) that was marginally significant ( $p \sim 0.05)$. Periwinkles occurred on both coralline types (and frequently on the cement surface of the platforms) at mean densities ranging from about 2 to 12 unit $^{-1}$ (Fig. 2). Limpets and chitons occurred almost exclusively on Phymatolithon and Lithothamnion, respectively (Figs. 3 \& 4), reflecting their natural microhabitat preferences (Table 1). Mean density of limpets in the Flush and Block treatments ranged from about 3 to 7 cobble $^{-1}$ on Phymatolithon in both experiments (Fig. 3). Mean density of chitons in the Flush and Block treatments ranged from about 3 to 5 cobble $^{-1}$ on Lithothamnion throughout Expt 1 and in November, February and May in Expt 2, but decreased in August 1986 to about 1 cobble $^{-1}$ in Expt 2 (Fig. 4).

The sizes (shell length) of periwinkles, limpets (on Phymatolithon) and chitons (on Lithothamnion) were similar between Flush and Block treatments at each sampling period in both experiments. Mean sizes (per treatment) ranged from 18 to $23 \mathrm{~mm}$ for periwinkles, 5 to $6 \mathrm{~mm}$ for limpets and 4 to $6 \mathrm{~mm}$ for chitons. The size distribution of each species on experimental units (not shown) closely approximated that on the natural cobble substratum at each sampling period (Scheibling \& Raymond 1990).

Among the non-manipulated mesograzers on the experimental platforms, Lacuna vincta, a small snail with a planktonic mode of dispersal, settled in abun- dance on filamentous red algae Polysiphonia harveyi that overgrew experimental cobbles in the Stilts treatment in fall 1985 (see Expt 1). In November 1985, mean densities of $L$. vincta ( 1 to $2 \mathrm{~mm}$ shell length) were about 1 and 4 cobble $^{-1}$ on Phymatolithon and Lithothamnion, respectively, in the Stilts treatment, although microscopic observations revealed numerous recently hatched individuals $(<1 \mathrm{~mm})$ on all treatments. Macroscopic L. vincta were not found in the Flush and Block treatments where other grazers precluded algal overgrowth (see Expt 1). L. vincta was rare $\left(<0.5\right.$ cobble $\left.^{-1}\right)$ in all other sampling periods in both experiments. Small amphipods (mainly Amphitoe rubricata) were the only other mesograzers found on experimental cobbles. Individuals 3 to $7 \mathrm{~mm}$ in body length occurred sporadically on Lithothamnion (with mean density of up to 5 cobble $^{-1}$ ) but were generally rare on Phymatholithon ( $<1$ cobble $^{-1}$ ). Amphipods and L. vincta may have contributed to the grazing effects we observed in our experiment, but given their minute size and paucity on experimental cobbles in most seasons, we expect their effect was small compared to that of the manipulated grazers.

\section{Expt 1: effects of mesograzers, elapsed time and type of coralline cover on algal colonization}

ANOVA of total algal biomass on cobbles in Expt 1 showed significant interactions between the grazing treatment and both time and coralline algal cover (Table 2), indicating that the effect of molluscan mesograzers differed between coralline types and over time. In the grazer exclusion (Stilts) treatment, both

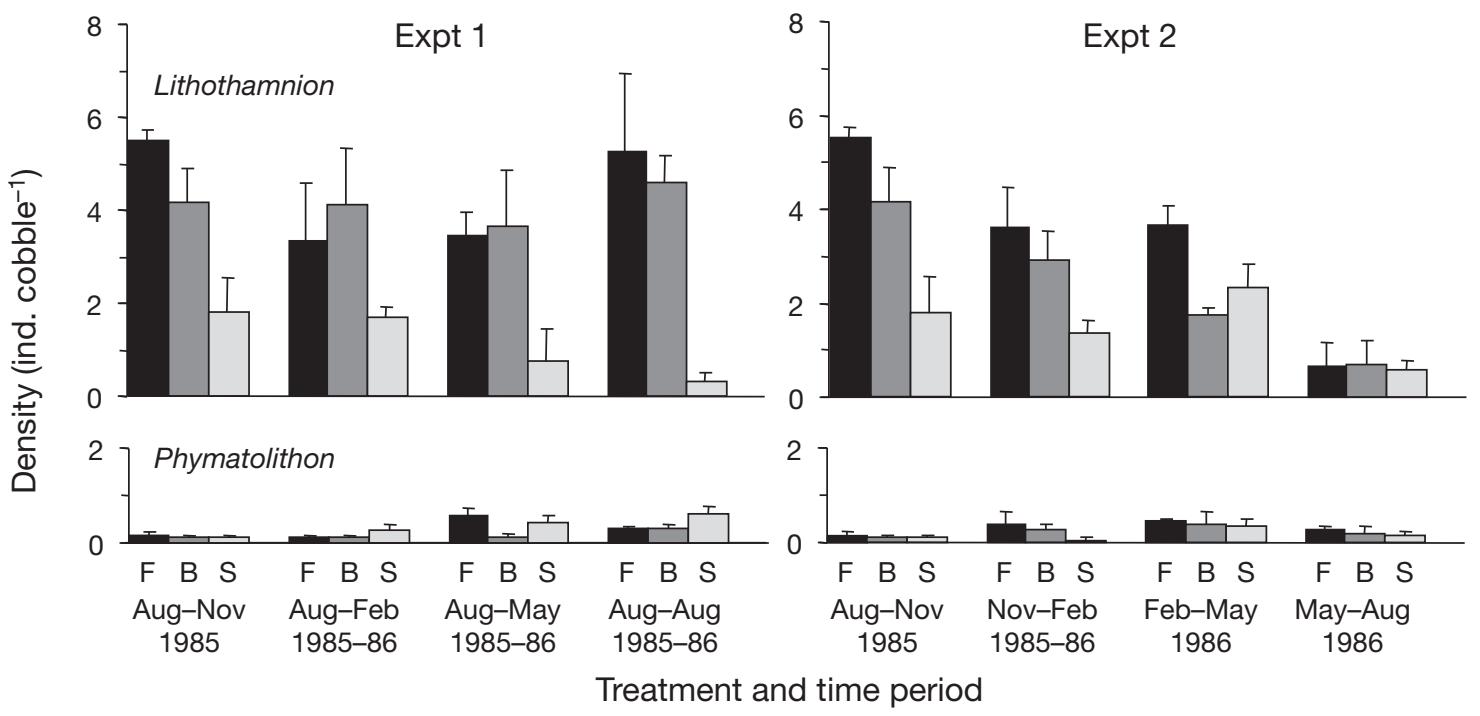

Fig. 4. Ischnochiton ruber. Mean (+SE, $\mathrm{n}=4$ ) density of chitons on experimental cobbles encrusted with Lithothamnion or Phymatolithon in each of 3 grazing treatments (F: Flush, grazer access; B: Block, grazer access and procedural control; S: Stilts, grazer exclusion) at 4 time periods in Expts 1 and 2 
Table 2. ANOVA results of effects on total algal biomass of grazing treatment, elapsed time and type of coralline cover in Expt 1. ns: not significant, $\mathrm{p}>0.05$

\begin{tabular}{|lccc|}
\hline Source & $\mathrm{df}$ & $F$ & $\mathrm{p}$ \\
\hline Block & 3 & 1.03 & $\mathrm{~ns}$ \\
Grazing & 2 & 162.18 & $<0.001$ \\
Time & 3 & 15.29 & $<0.001$ \\
Grazing $\times$ Time & 6 & 2.66 & $<0.05$ \\
Main-plot error & 33 & & \\
Coralline & 1 & 21.92 & $<0.001$ \\
Grazing $\times$ Coralline & 2 & 1.34 & $\mathrm{~ns}$ \\
Time $\times$ Coralline & 3 & 9.36 & $<0.001$ \\
Grazing $\times$ Time $\times$ Coralline & 6 & 7.08 & $<0.001$ \\
Sub-plot error & 36 & & \\
\hline
\end{tabular}

coralline types were rapidly overgrown by filamentous red algae Polysiphonia harveyi in fall 1985. Mean algal biomass in the Stilts treatment remained relatively constant at 3 to $5 \mathrm{mg} 10 \mathrm{~cm}^{-2}$ between 3 and $6 \mathrm{mo}$ on Lithothamnion, and between 3 and 9 mo on Phymatolithon, but then increased sharply to $17-20 \mathrm{mg}$ $10 \mathrm{~cm}^{-2}$ by 9 mo on Lithothamnion and by $12 \mathrm{mo}$ on Phymatolithon (Fig. 5). In marked contrast, algal colonization was limited on Lithothamnion and effec- tively precluded on Phymatolithon by mesograzers in the Flush and Block treatments (Fig. 5). Mean algal biomass on Lithothamnion did not differ significantly ( $p>0.05$ ) between Flush and Block treatments at 3, 6 or 9 mo, indicating no effect of elevation, but was significantly higher on the Block treatment at 12 mo $(\mathrm{p}<$ 0.05). Mean algal biomass was significantly higher in the Stilts treatment than in the corresponding Block treatment at all sampling periods ( $\mathrm{p}<0.05)$. Although depth increased gradually from 2.5 to $3 \mathrm{~m}$ at one end of the experimental array, and the units around the middle occasionally were inundated by drift algae, the block effect was nonsignificant (Table 2), indicating that spatial gradients in environmental conditions along the array were a relatively unimportant source of variability in algal biomass on experimental cobbles.

The algal assemblage in the Stilts treatment progressively changed in composition, thallus size and density. A similar succession of ephemeral species occurred on both coralline types. The dense monoculture of Polysiphonia harveyi, which blanketed the cobbles in the first 3 mo of the experiment (Fig. 1a), was gradually replaced by another filamentous red alga Ceramium rubrum, a plumose brown alga Desmarestia viridis and a variety of less abundant foliose and filamentous red (including 3 congeneric species of Polysiphonia), brown and green algae (Fig. 6, Table A1 in Appen-

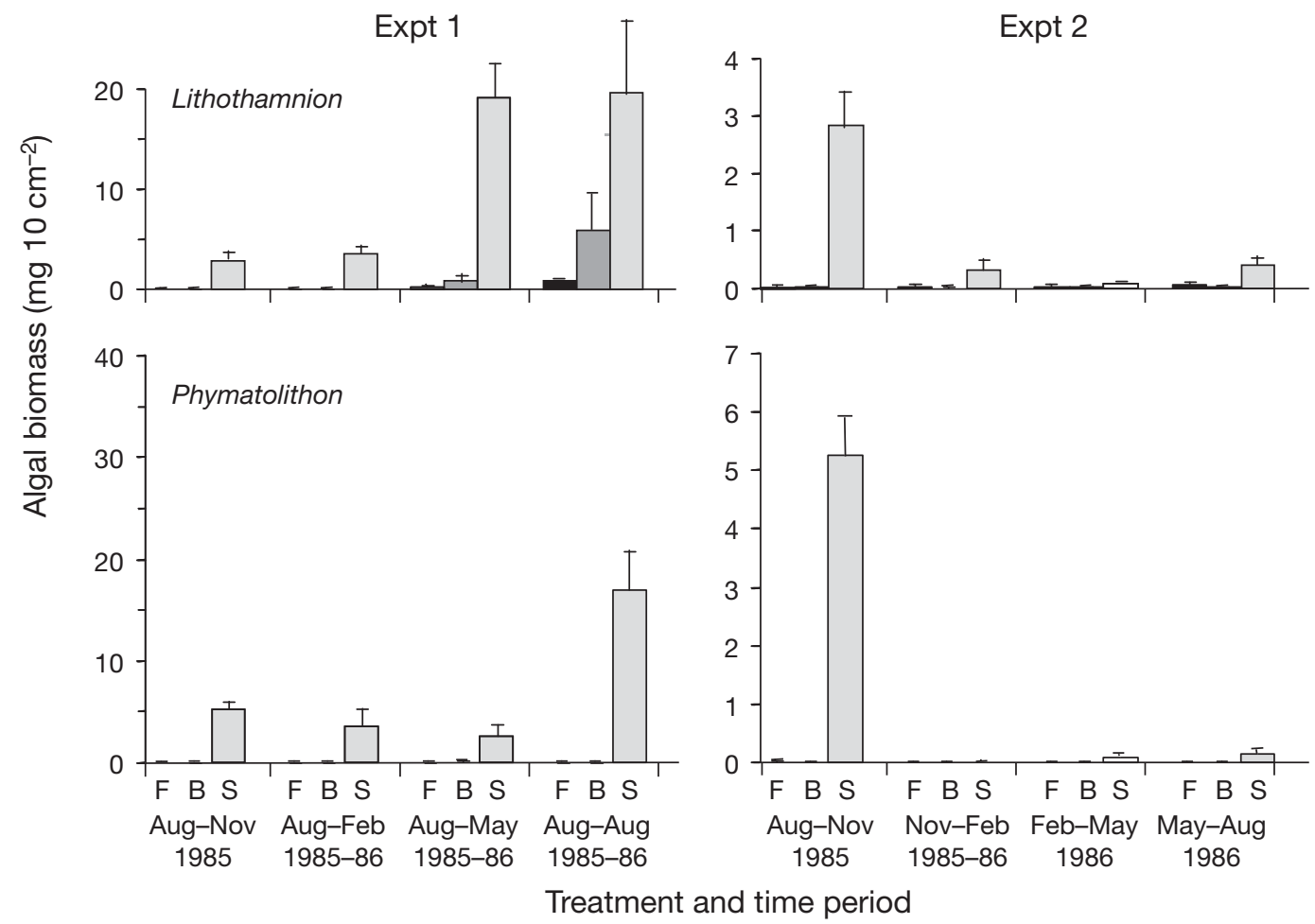

Fig. 5. Mean $(+\mathrm{SE}, \mathrm{n}=4)$ biomass of erect macroalgae on experimental cobbles encrusted with Lithothamnion or Phymatolithon in each of 3 grazing treatments (F: Flush, grazer access; B: Block, grazer access and procedural control; S: Stilts, grazer exclusion) at 4 time periods in Expts 1 and 2 
dix 1, see www.int-res.com/articles/suppl/m382p113_ app.pdf). A few germlings of Fucus evanescens occurred on Lithothamnion at all sampling periods and small kelp sporophytes occasionally were found on each coralline type. These juveniles of large perennial species rarely exceeded $20 \mathrm{~mm}$ in length in the Stilts treatment and their contribution to the total algal biomass was negligible (Table A1). Algal density on cobbles in the Stilts treatment decreased with time as individual thalli grew larger. A gradual thinning of Polysiphonia harveyi during the first 6 mo was compensated by the growth of remaining plants, such that its biomass remained relatively constant (Fig. 6). A filamentous red alga Bonnemaisonia hamifera and diatoms occurred as epiphytes on the larger plants. Increases in total algal biomass on Lithothamnion after 6 mo and on Phymatolithon after 9 mo were due mainly to the growth of established plants, particularly Ceramium rubrum and Desmarestia viridis, rather than to recruitment and growth of new colonists or epiphytes.

The dense cover of filamentous algae on the Stilts treatment acted as a baffle to water movement, which increased sediment deposition. Consequently, the cobbles often were covered with a thin film of silt and fine sand. The coralline crusts, however, remained viable beneath this film and overlying algal canopy, and were no different in appearance from those on the heavily grazed cobbles in the Flush and Block treatments. Small patches (usually $<1 \mathrm{~cm}^{2}$ ) of another smooth coralline crust Clathromorphum circumscriptum were observed on some of the Phymatolithon cobbles, particularly in the Flush and Block treatments at 9 and 12 mo. We were unable to distinguish whether Clathromorphum had colonized during the course of the experiment or had grown from smaller individuals present at the onset (the selection criterion for Phymatolithon cobbles was $>95 \%$ cover of Phymatolithon). A few of the patches exceeded $5 \%$ of the exposed surface area of the cobble, suggesting overgrowth of Phymatolithon by Clathromorphum. There was no evidence of colonization or overgrowth of Lithothamnion by Clathromorphum or Phymatolithon.

In the Flush and Block treatments, mean biomass of most algal species was $<0.1 \mathrm{mg} 10 \mathrm{~cm}^{-2}$ at all sampling periods (Table A1). The higher total biomass on Lithothamnion in the Block relative to the Flush treatment at 12 mo was due to only a few thalli of Desmarestia viridis (which accounted for $87 \%$ of the total biomass). Fucus evanescens, the perennial dominant on the natural cobble bottom, was consistently present on Lithothamnion on all grazing treatments. Individual size of $F$. evanescens progressively increased in the Flush and Block treatments as small germlings, only 2-8 mm length at $3 \mathrm{mo}$, grew to 26-39 $\mathrm{mm}$ by $12 \mathrm{mo}$ (Fig. 1d). In contrast, $F$. evanescens in the Stilts treatment remained small (<15 mm). Chondrus crispus, another common perennial species in the cobble bed, occurred sporadically on Lithothamnion on grazed treatments (Table A1) and only as small juvenile thalli $<30 \mathrm{~mm}$ length. A juvenile kelp, Saccorhiza dermatodea (115 mm length), occurred on Lithothamnion in the Block treatment at 12 mo (Table A1).

Algal species richness was low (1 to 4 species) at 3 mo, when Polysiphonia harveyi dominated the cover, and progressively increased in the Stilts treatment to 11 and 16 species on Phymatolithon and Lithothamnion, respectively, by 9 mo (Fig. 7). In the Flush and Block treatments, richness remained low on Phymatolithon throughout the experiment ( 0 to 3 species) and on Lithothamnion during the first 9 mo (2 to 5 species), but increased to 10-13 species on Lithothamnion (comparable to the Stilts treatment) by $12 \mathrm{mo}$.

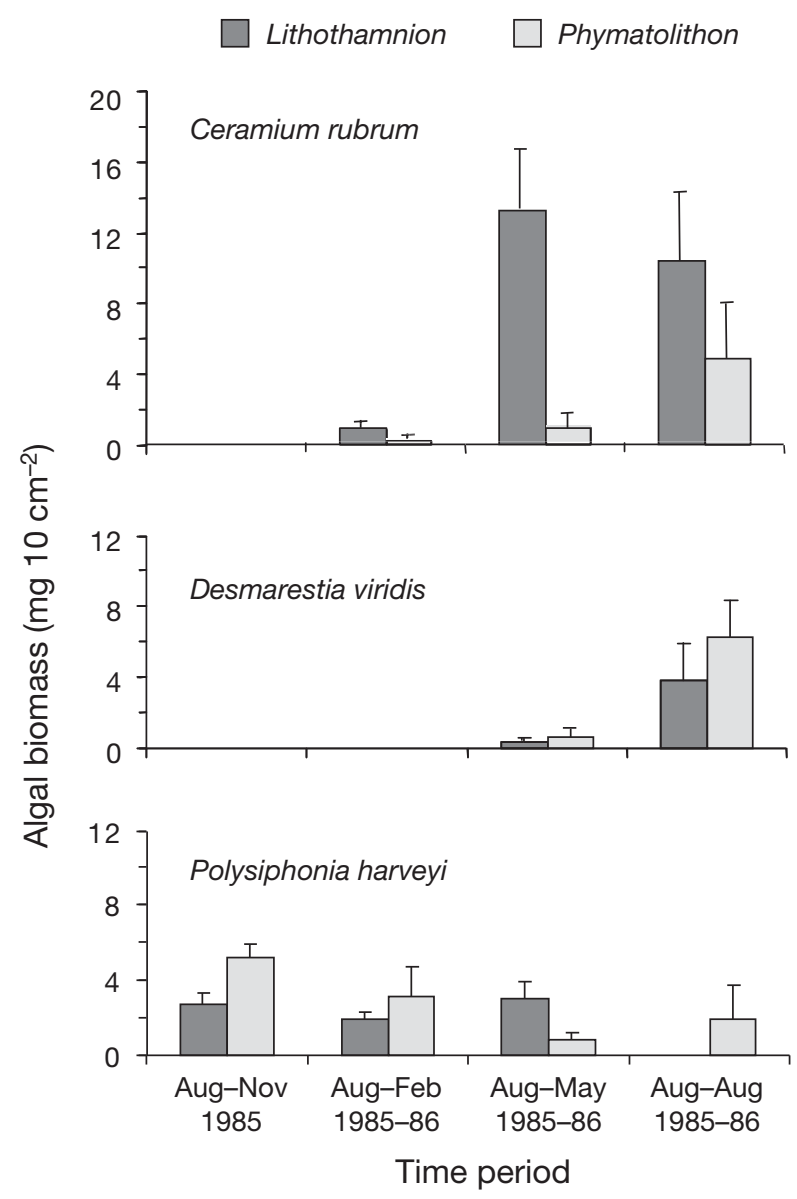

Fig. 6. Mean $(+\mathrm{SE}, \mathrm{n}=4)$ biomass of the 3 most abundant algal species ( $\geq 1 \mathrm{mg} 10 \mathrm{~cm}^{-2}$ at 2 or more sampling times) on cobbles encrusted with Lithothamnion or Phymatolithon in the Stilts (grazer exclusion) treatment at 4 time periods in Expt 1 
NMDS ordination showed that macroalgal assemblages on Lithothamnion in the Flush and Block treatments clustered separately from assemblages on both Lithothamnion and Phymatolithon in the Stilts treatment (Fig. 8). (Flush and Block treatments with Phymatolithon were excluded from this analysis because of the low numbers of species present.) Assemblages in the Flush and Block treatments on Lithothamnion were similar at 3,6 and $12 \mathrm{mo}$, but less so at 9 mo. Assemblages on Lithothamnion and Phymatolithon in the Stilts treatment developed similarly over the course of the 12 mo experiment (Fig. 8).

Juvenile mussels Modiolus modiolus and Mytilus edulis ( 2 to $5 \mathrm{~mm}$ shell length) were consistently found, albeit at low abundance, on experimental cobbles after the first 3 mo (Table A1). They occurred primarily on Lithothamnion in all grazer treatments (mean densities were $<2$ cobble $^{-1}$, except 3 and 4 cobble $^{-1}$ in the Flush treatment at 6 and 12 mo, respectively) and were rare on Phymatolithon (usually $<0.5$ cobble $^{-1}$ ). Small clams Hiatella arctica and saddle oysters Anomia sp. (2 to $5 \mathrm{~mm}$ shell length) also were found mainly on Lithothamnion, but in very low numbers $(<0.3$ per cobble) (Table A1).

Expt 1

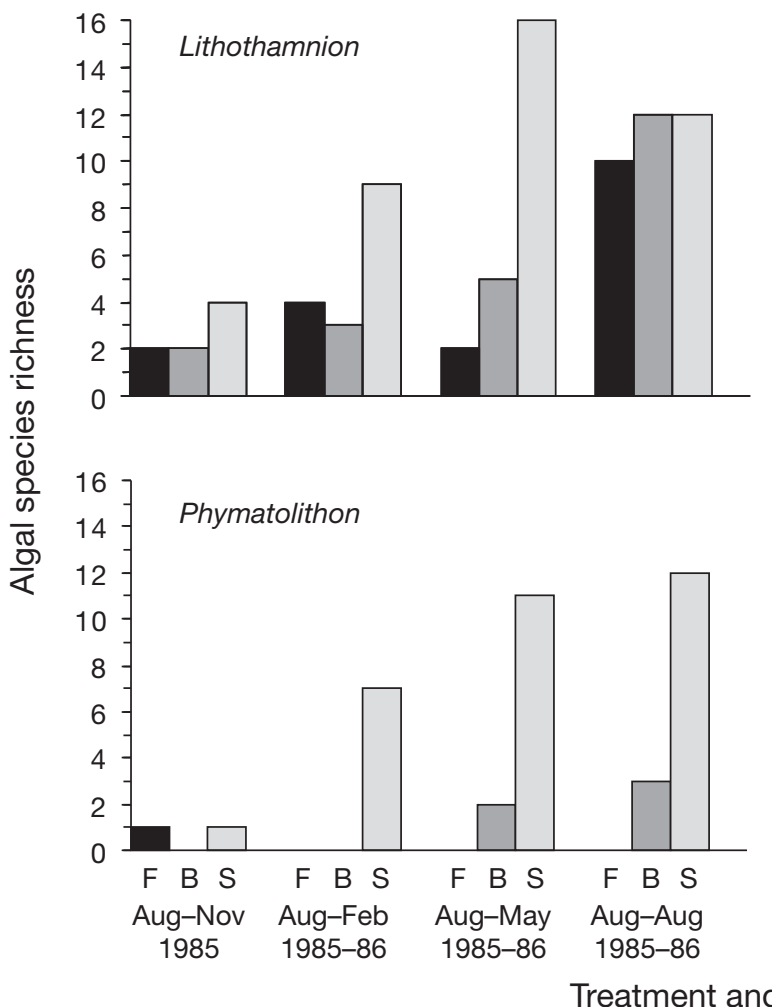

\section{Expt 2: effects of mesograzers, season and type of coralline algal cover on algal colonization}

ANOVA of the total algal biomass on cobbles in Expt 2 showed significant interactions between grazing treatment, season and coralline type (Table 3 ). The seasonal effect was striking: following the heavy recruitment of Polysiphonia harveyi in fall 1985, algal colonization in subsequent seasons was minimal (Fig. 5). The limiting effect of molluscan mesograzers on algal recruitment was particularly evident in November 1985, when $P$. harveyi formed a dense monoculture covering both coralline types in the Stilts treatment but was rare or absent in the Flush and Block treatments. In subsequent sampling periods, grazer effects were not apparent on Phymatolithon and were far less pronounced on Lithothamnion (Fig. 5). Both coralline types in the Stilts treatment developed a thin cover of diatoms (Licomorpha, Meridion) and filamentous microalgae; a small leafy green alga (Monostroma sp.) also was present on Phymatolithon (Table A2 in Appendix 1, see www.int-res.com/articles/suppl/ m382p113_app.pdf). A sparse cover of filamentous red algae (Polysiphonia spp, Ceramium rubrum) occurred

Expt 2
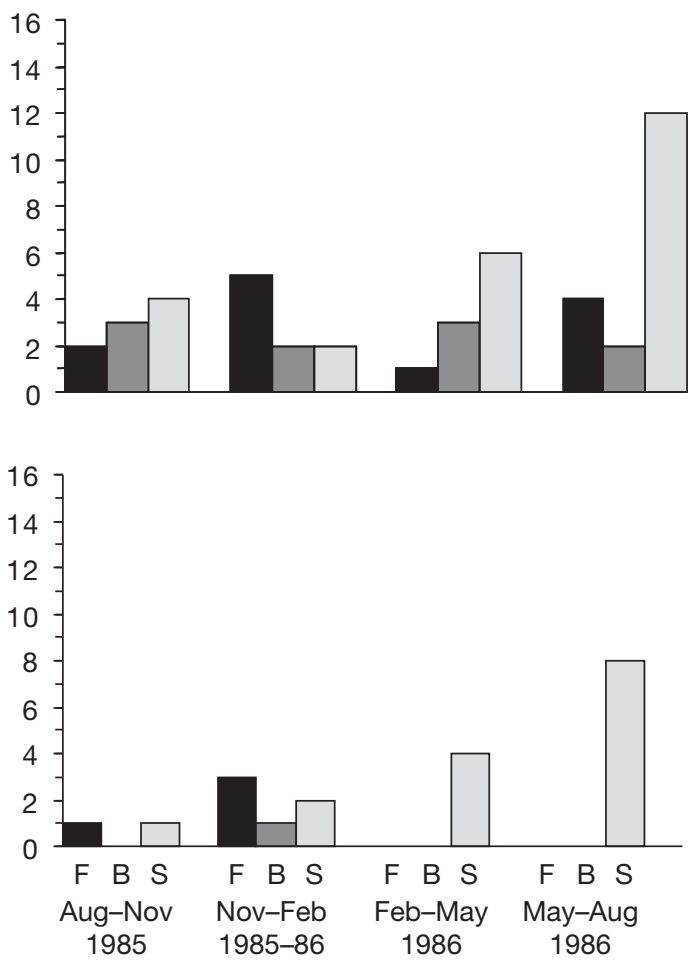

Fig. 7. Species richness of algae on experimental cobbles encrusted with Lithothamnion or Phymatolithon in each of 3 grazer treatments (F: Flush, grazer access; B: Block, grazer access and procedural control; S: Stilts, grazer exclusion) at 4 time periods in Expts 1 and 2. Species counts are pooled over all cobbles from 4 replicates 


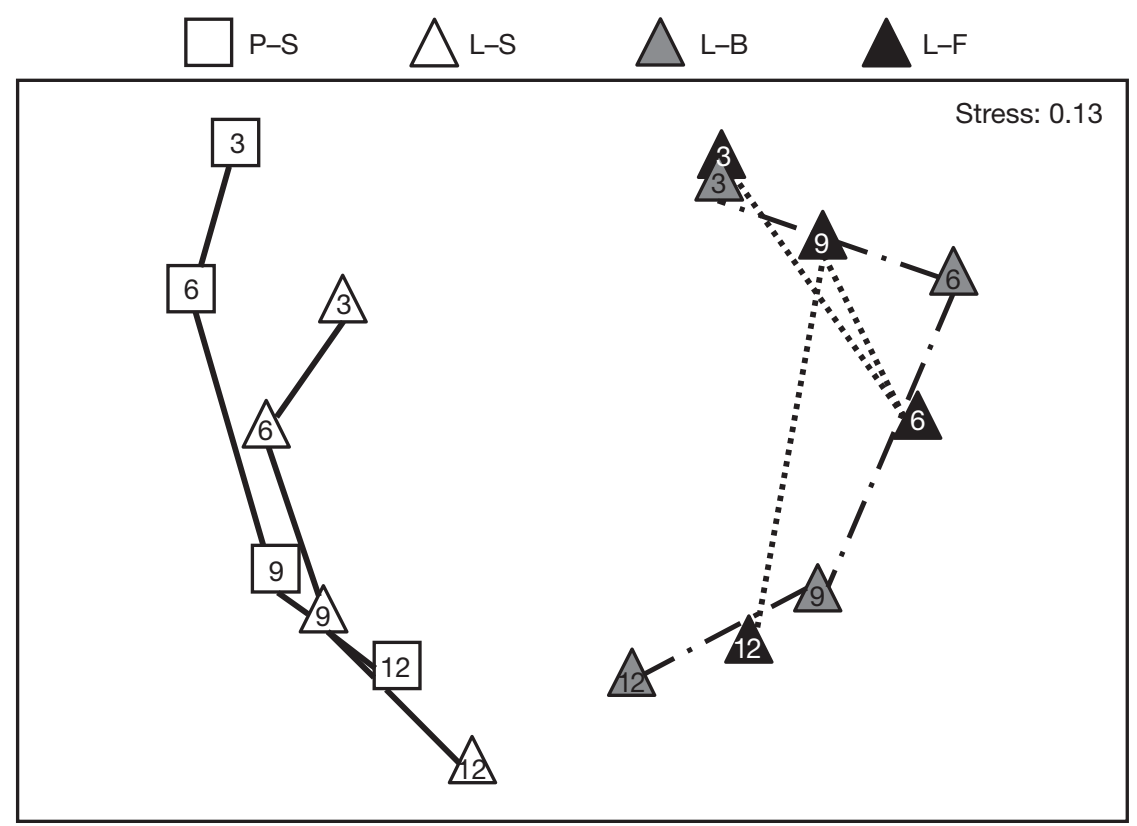

Fig. 8. Non-metric multi-dimensional scaling (nMDS) plot of the macroalgal assemblages on experimental cobbles encrusted with Lithothamnion (L) or Phymatolithon $(\mathrm{P})$ in each of 3 grazing treatments (F: Flush, grazer access; B: Block, grazer access and procedural control; S: Stilts, grazer exclusion) at 4 time periods (elapsed time: 3, 6, 9 and $12 \mathrm{mo}$ ) in Expt 1

on both coralline types in the Stilts treatment in August 1986, although this amounted to only a small fraction of the algal biomass recorded the previous November (Table A2). At each sampling period, a few germlings of Fucus evanescens (<10 mm length) were found on Lithothamnion in all grazing treatments. Macroalgal species richness was low in the Flush and Block treatments (usually $<3$ species) on both coralline types at all sampling periods (Fig. 7). Richness was highest in the Stilts treatment in May and August 1986, ranging from 4 to 12 species on both coralline types.

As in Expt 1, juvenile mussels were found on Lithothamnion in all grazing treatments, but rarely on Phymatolithon (Table A2). Mean densities of mussels on Lithothamnion were $<2$ cobble $^{-1}$ in February and May 1986, but increased to $2-4$ cobble $^{-1}$ by August, as in Expt 1. Small clams Hiatella arctica and saddle oysters Anomia sp. occurred sporadically and at low numbers $\left(<0.5\right.$ cobble $\left.^{-1}\right)$, but only on Lithothamnion (Table A2).

\section{Expt 3: effects of different mesograzers on algal colonization}

In Expt 3, as in Expts 1 \& 2, periwinkles were consistently observed (although density was not measured) in the control (Flush) treatment but not in the 2 grazer exclusion (Stilts) treatments. Limpets occurred exclusively on Phymatolithon: mean densities were $\sim 1$ and 3 cobble $^{-1}$ in the periwinkle exclusion and control treatment, respectively; limpets were absent in the periwinkle/limpet exclusion treatment. Chitons occurred on Lithothamnion, at mean densities of 2 to 3 cobble $^{-1}$ in all treatments, but were rare $\left(<1\right.$ cobble $\left.^{-1}\right)$ or absent on Phymatolithon.

At the end of the experiment (6 December 1985), a monoculture of Polysiphonia harveyi (>99\% of algal biomass) overgrew cobbles to varying extents in the grazer exclusion treatments, but was absent in the control (Fig. 9). Mean algal biomass on Phymatolithon was significantly greater when both periwinkles and limpets were excluded than when only periwinkles were excluded (1-tailed $t$-test, log-transformed data: $t=6.18, \mathrm{p}<0.025)$, indicating that limpets alone can markedly limit algal colonization on Phymatolithon. Although chitons were not manipulated, the abundance of macroalgae on Lithothamnion in the 2 grazer

Table 3. ANOVA results of effects on total algal biomass of grazing treatment, season and type of coralline cover in Expt 2. ns: not significant, $p>0.05$

\begin{tabular}{|lccc|}
\hline Source & df & $F$ & $\mathrm{p}$ \\
\hline Block & 3 & 2.52 & $\mathrm{~ns}$ \\
Grazing & 2 & 308.60 & $<0.001$ \\
Season & 3 & 166.53 & $<0.001$ \\
Grazing $\times$ Time & 6 & 167.49 & $<0.001$ \\
Main-plot error & 33 & & \\
Coralline & 1 & 9.95 & $<0.01$ \\
Grazing $\times$ Coralline & 2 & 12.30 & $<0.001$ \\
Season $\times$ Coralline & 3 & 8.19 & $<0.001$ \\
Grazing $\times$ Season $\times$ Coralline & 6 & 7.85 & $<0.001$ \\
Sub-plot error & 36 & & \\
\hline
\end{tabular}


exclusion treatments, which did not differ significantly (2-tailed $t$-test: $t=1.09, \mathrm{p}>0.30$ ), and its absence in the control treatment indicate that chitons are relatively unimportant, when compared to periwinkles, in controlling algal colonization on Lithothamnion.

\section{Urchin grazing experiment}

Grazing by adult sea urchins Strongylocentrotus droebachiensis enclosed in cages on the cobble bottom markedly reduced the abundance of fleshy brown algae Fucus evanescens and red algae Chondrus crispus after 3 mo (Fig. 10). Biomass of both species (Fig. 10a) was significantly lower in cages with urchins than in control cages (1-tailed $t$-test, log-transformed data: $F$. evanescens, $t=4.66, \mathrm{p}=0.005 ; C$. crispus, $t=$ $2.89, \mathrm{p}=0.005$ ). Percentage cover of both species combined (Fig. 10b) was also significantly lower in cages with urchins than in control cages (1-tailed $t$-test, arcsine-transformed data: $t=5.64, \mathrm{p}=0.003$ ). Biomass of the geniculate coralline alga Corallina officinalis did not differ significantly between the 2 treatments $(t=$ $1.29, p=0.133)$. In addition to grazing attached algae, caged urchins probably also consumed algal detritus that drifted into the cages, as they often held algal fragments on their aboral side with their tube feet. Mesograzers such as periwinkles, chitons and limpets could pass freely in and out of the cages and were common in all treatments. There were no significant differences in the cover or biomass of erect macroalgae between control cages and unmanipulated plots (2tailed $t$-test, $p>0.20$ ), indicating that caging had no effect on algal abundance during the experiment. The 3 species that we analyzed accounted for $>97 \%$ of the total macroalgal biomass in each treatment.

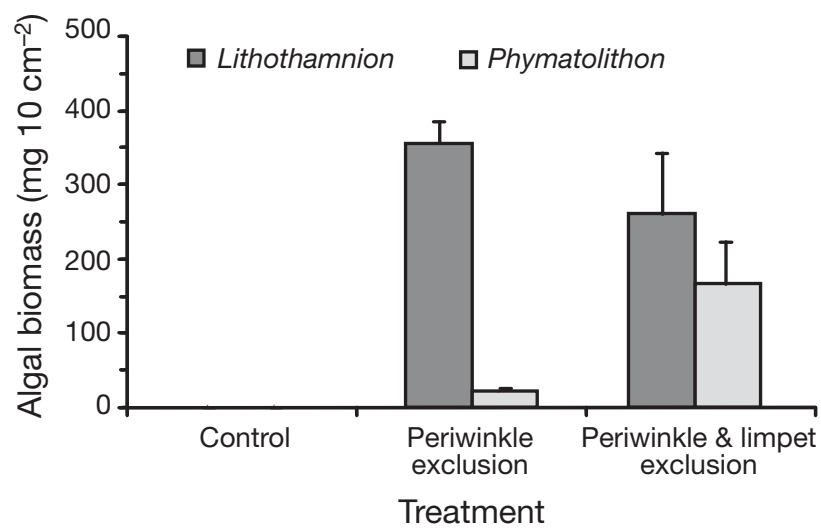

Fig. 9. Mean $(+\mathrm{SE}, \mathrm{n}=2)$ biomass of erect macroalgae on experimental cobbles encrusted with Lithothamnion or Phymatolithon in each of 3 grazing treatments in Expt 3: control (Flush, grazer access), periwinkle exclusion (Stilts 2), and periwinkle and limpet exclusion (Stilts 1)

\section{DISCUSSION}

Following the mass mortality of Strongylocentrotus droebachiensis in 1983, high densities of molluscan mesograzers regulated the colonization, diversity and succession of the macroalgal assemblage of the cobble bed at Eagle Head, Nova Scotia, Canada. Experimental exclusion of periwinkles, limpets and chitons from cobbles resulted in the establishment of a variety of filamentous algae and surface films that were not observed in the cobble bed (Scheibling \& Raymond 1990). Periwinkles Littorina littorea and limpets Testudinalia testudinalis had the greatest effects on the epiphytic algal assemblage on Lithothamium- and Phymatolithonencrusted cobbles, respectively. Limpets and chitons rasp the epithallial layers of coralline crusts, consuming microalgae and propagules of epiphytic macroalgae (Steneck 1982, Steneck \& Watling 1982). Periwinkles are generalists, consuming both microalgal films and small filamentous and foliose macroalgae (Lubchenco 1978, Steneck \& Watling 1982). This abundant guild of mesograzers appears to be the dominant agent of early mortality of macroalgae in the cobble bed.

Some fleshy algae occasionally escaped grazing long enough to attain a growth refuge on the cobbles. Juvenile thalli of Chondrus crispus and Fucus evanescens ( 3 to $4 \mathrm{~cm}$ in length) occurred sporadically in grazed treatments, and a juvenile kelp Saccorhiza dermatodea grew to $\sim 12 \mathrm{~cm}$ in the Block treatment. Although F. evanescens juveniles are consumed by Littorina littorea (Petraitis 1987, Barker \& Chapman 1990), individuals larger than 3 to $5 \mathrm{~cm}$ are relatively immune to periwinkle grazing (Lubchenco 1983). When urchins were reintroduced into the cobble bed in cages, the assemblage reverted to the barrens state, with urchins consuming all non-coralline algae including the larger fleshy perennials that had escaped the molluscan grazers.

In the absence of urchins and molluscan mesograzers, a similar succession of ephemeral macroalgae occurred over time on both coralline types. The dense monoculture of Polysiphonia harveyi, which dominated the assemblage for the first 6 mo on both coralline types, was gradually replaced by Ceramium rubrum, Desmarestia viridis and a variety of less abundant foliose and filamentous red, brown and green algae. Fucoids and kelps were present but at very low biomass. The macroalgal assemblage in the Stilts treatment after 12 mo was similar to that observed on a nearby boulder field $1 \mathrm{yr}$ after the urchin mass mortality (Scheibling 1986), indicating that it represented an early successional stage in the development of a kelp bed.

Algal species richness increased over time on both Lithothamnion and Phymatolithon, and was greatest in treatments with the greatest algal biomass. The 
increase in biomass on Lithothamnion after 6 mo and on Phymatolithon after 9 mo was primarily due to the growth of established plants, since algal recruitment peaked in fall 1985 and was low thereafter. In the absence of grazing, established foliose and filamentous algae may have facilitated colonization and/or survival of less common, late successional species by retaining algal propagules and enhancing settlement (Eckman 1983, Duggins et al. 1990, Smith \& Witman 1999, Bruno \& Bertness 2001), modifying near-bottom flows (Gambi et al. 1990, Worcester 1995) or providing attachment sites for epiphytes (Heck \& Wetstone 1977 , Turner 1983).

The small-scale structural complexity provided by Lithothamnion crusts may also have facilitated the colonization and recruitment of macroalgae and sessile invertebrates to the cobbles. Algal biomass and species richness were greater on Lithothamnion than Phymatolithon (over all treatments), suggesting that the rugose morphology of Lithothamnion may have provided cryptic microhabitats for recruitment of some species (e.g. chitons, mussels and Fucus evanescens), influenced the deposition and retention of larvae and
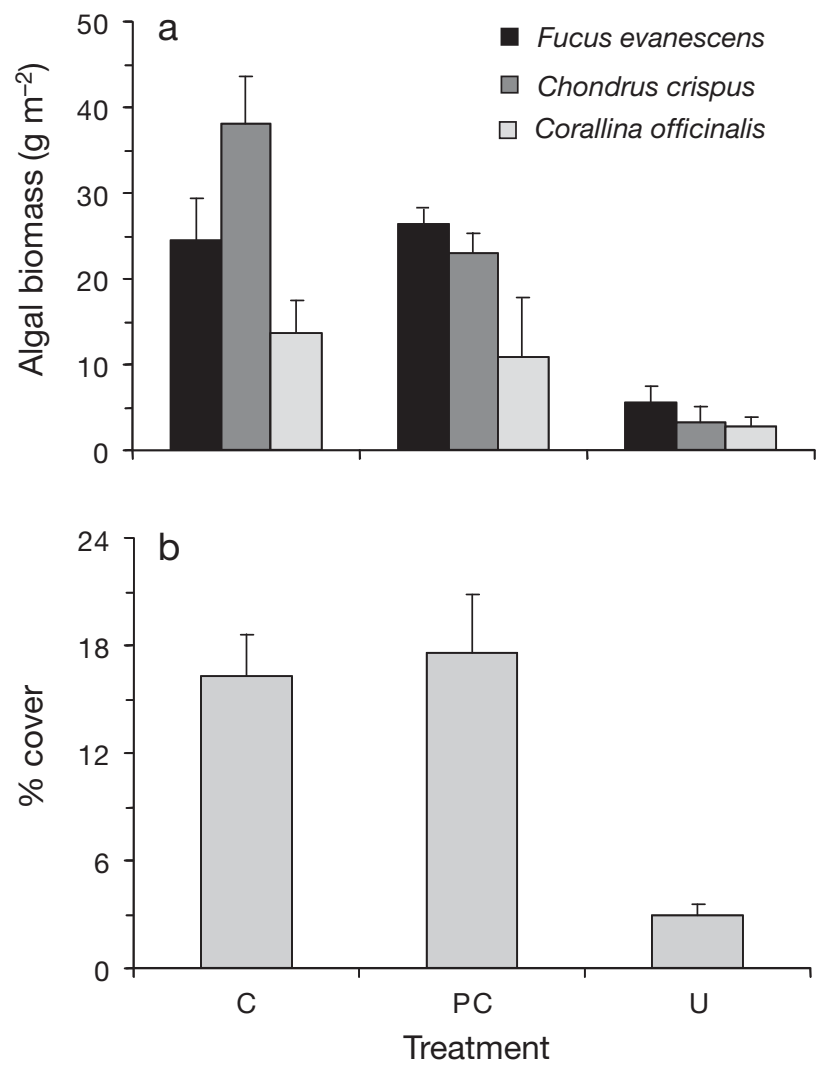

Fig. 10. (a) Mean (+SE, $\mathrm{n}=3$ ) biomass of erect macroalgae and (b) percent cover of Fucus evanescens and Chondrus crispus (combined) on the cobble bed in each of 3 treatments (C: unmanipulated control; PC: caged control; U: urchin inclusion treatment) in the urchin grazing experiment algal propagules (Harlin \& Lindbergh 1977), or provided protection (on the Flush and Block treatments) from predators and grazers (Harris et al. 1984, Steneck 1986, Robson 1996). Also, the distribution of mesograzers differed between coralline types, likely influencing the rate and intensity of grazing between Lithothamnion- and Phymatolithon-encrusted cobbles. While periwinkles foraged on both types of crust, limpets and chitons occurred primarily on Phymatolithon and Lithothamnion, respectively. Chitons have a polyplacate articulated shell that allows them to maneuver among the small recesses and nubbly branches of Lithothamnion, while limpets have a monoplacate shell that precludes all but the smallest individuals from the pits and recesses between these branches (Scheibling \& Raymond 1990). While limpets alone were found to markedly limit algal colonization on Phymatolithon, chitons appeared to be relatively unimportant when compared to periwinkles in controlling colonization on Lithothamnion. Thus, the physical restriction of limpets to Phymatolithon-encrusted cobbles likely decreased the grazing pressure on macroalgae that colonized Lithothamnion.

In rocky intertidal habitats, Lubchenco (1978, 1980, 1983) demonstrated a hierarchy of asymmetrical competitive relationships among algae, such that Chondrus crispus and Fucus evanescens are inferior competitors to ephemeral algae and rely on periwinkle grazing to provide free space for colonization. In the present study, the greatest biomass of C. crispus and $F$. evanescens occurred on Lithothamnion-encrusted cobbles when urchins were absent but molluscan grazers were present. When both urchins and molluscan grazers were absent, biomass of $F$. evanescens was low and $C$. crispus was absent from cobbles. Our results represent a subtidal extension of Lubchenco's $(1978,1980,1983)$ findings in that molluscan grazers appear to facilitate colonization and/or growth of $F$. evanescens and C. crispus by removing inhibitive effects of early successional species. In the absence of urchins, this herbivore-algal interaction may play a key role in mediating succession of macroalgae on cobbles. Free space maintained by mesograzers may also have facilitated colonization by bivalves by reducing competition with epiphytic macroalgae on Lithothamnion (Lubchenco 1978, 1983, Lubchenco \& Menge 1978, but see McCook \& Chapman 1997). Mussels on rocky shores settle predominantly around surface heterogeneities (Petraitis 1990, McCook \& Chapman 1991), which may account for their greater abundance on this rugose crust compared to Phymatolithon.

Previous studies have demonstrated that physical disturbance is the primary determinant of macroalgal community organization on cobbles in subtidal habi- 
tats (Osman 1977, Lieberman et al. 1979, 1984, Davis \& Wilce 1987). However, unlike at the cobble bed at Eagle Head, urchins and other invertebrate grazers were typically rare or absent in these studies. While gradual overturning of cobbles occurs at Eagle Head, we observed minimal displacement (generally $<0.5 \mathrm{~m}$ ) of cobbles, even after periods of 9 to $12 \mathrm{mo}$, suggesting that cobbles are relatively stable and their movement is not a major source of damage for macroalgae that colonize them (Scheibling et al. 2008). The stability and small-scale structural complexity of the cobble matrix likely promotes the persistence of molluscan grazers by providing spatial refuges from predators (Scheibling \& Hamm 1991). Thus, biological agents of disturbance appear to outweigh physical ones as the primary force controlling early community organization at Eagle Head.

In conclusion, our experimental results were consistent with predictions based on each of our original hypotheses. We showed that high densities of molluscan mesograzers can limit the abundance and diversity of macroalgal assemblages in a subtidal cobble bed when urchins are rare or absent. Rates of algal colonization vary seasonally and a greater biomass of algae accumulates on rugose than smooth crusts. While periwinkles, limpets and chitons prevent the establishment of foliose and filamentous ephemeral algae, larger fleshy algae, such as fucoids and kelps, occasionally escape grazing by attaining a size refuge. However, once these algae attain a critical size (a function of the biomass of the alga relative to the mass of cobble to which it is attached) they are displaced, along with the cobble, by hydrodynamic forces acting on the algal fronds (Scheibling et al. 2008). Fleshy algal species that escape molluscan grazing are eventually transported out of the cobble bed and deposited on the shore or in the deeper muddy regions of the basin, where they ultimately decompose or are consumed by detritivores. Therefore, as a consequence of biological and physical agents of disturbance operating at different life history stages, the algal assemblage of the cobble bed converges on a sparse turf of low-lying perennial species (mainly Fucus evanescens and Chondrus crispus) following the mass mortality of urchins. A return to this site in August 2007 revealed little change in the algal and grazer assemblages of the cobble bed after 20 yr (R. Scheibling pers. obs.), suggesting these processes could maintain the benthic community at a near equilibrium state, one that differs markedly from the assemblage of large, canopy-forming macroalgae on adjacent boulder and bedrock substrata.

Acknowledgements. We thank G. Croft for diving assistance, D. Roberts-Regan and A. Griswold for assistance with sample processing and A. R. O. Chapman and C. Bird for identifying many of the algal species. We also thank D. Duggins and 2 anonymous reviewers for comments on an earlier draft of this paper. The research was funded by grants from the Natural Sciences and Engineering Research Council (NSERC) to R.E.S.

\section{LITERATURE CITED}

Anderson MJ, Underwood AJ (1997) Effects of gastropod grazers on recruitment and succession of an estuarine assemblage: a multivariate and univariate approach. Oecologia 109:442-453

Ayling AM (1981) The role of biological disturbance in temperate subtidal encrusting communities. Ecology 62: 830-847

Barker KM, Chapman ARO (1990) Feeding preferences of periwinkles among four species of Fucus. Mar Biol 106: 113-118

Benedetti-Cecchi L (2000) Predicting direct and indirect interactions during succession in a mid-littoral rocky shore assemblage. Ecol Monogr 70:45-72

> Benedetti-Cecchi L, Bulleri F, Cinelli F (2000) The interplay of physical and biological factors in maintaining mid-shore and low-shore assemblages on rocky coasts in the northwest Mediterranean. Oecologia 123:406-417

Boaventura D, Alexander M, Santina PD, Smith ND, Re P, Fonseca LC, Hawkins SJ (2002) The effects of grazing on the distribution and composition of low-shore algal communities on the central coast of Portugal and on the southern coast of Britain. J Exp Mar Biol Ecol 267:185-206

Brawley S (1992) Mesoherbivores. In: John DM, Hawkins SJ, Price JH (eds) Plant-animal interactions in the marine benthos. Clarendon Press, Oxford, p 235-263

Breitburg DL (1985) Development of a subtidal epibenthic community: factors affecting species composition and the mechanisms of succession. Oecologia 65:173-184

Bruno JF, Bertness MD (2001) Habitat modification and facilitation in benthic marine communities. In: Bertness MD, Gaines SD, Hay ME (eds) Marine community ecology. Sinauer Associates, Sunderland, MA, p 201-218

Carpenter RC (1986) Partitioning herbivory and its effects on coral reef algal communities. Ecol Monogr 56:345-364

Carpenter RC (1990) Mass mortality of Diadema antillarum. I. Long-term effects on sea urchin population-dynamics and coral reef algal communities. Mar Biol 104:67-77

Clarke KR, Warwick RM (1994) Change in marine communities: an approach to statistical analysis and interpretation. Natural Environment Research Council, London

> Davis AN, Wilce RT (1987) Algal diversity in relation to physical disturbance: a mosaic of successional stages in a subtidal cobble habitat. Mar Ecol Prog Ser 37:229-237

Dethier MN, Duggins DO (1984) An 'indirect commensalism' between marine herbivores and the importance of competitive hierarchies. Am Nat 124:205-219

> Duggins DO, Dethier MN (1985) (1985) Experimental studies of herbivory and algal competition in a low intertidal habitat. Oecologia 67:183-191

$>$ Duggins DO, Eckman JE, Sewell AT (1990) Ecology of understory kelp environments. II. Effects of kelps on recruitment of benthic invertebrates. J Exp Mar Biol Ecol 143:27-45

Eckman JE (1983) Hydrodynamic processes affecting benthic recruitment. Limnol Oceanogr 28:241-257

- Farrell TM (1988) Community stability: effects of limpet removal and reintroduction in a rocky intertidal community. Oecologia 75:190-197

Farrell TM (1991) Models and mechanisms of succession: an example from a rocky intertidal community. Ecol Monogr 61:95-113 
Gambi MC, Nowell ARM, Jumars PA (1990) Flume observations on flow dynamics in Zostera marina (eelgrass) beds. Mar Ecol Prog Ser 61:159-169

Gomez KA, Gomez AA (1984) Statistical procedures for agricultural research, 2nd ed. John Wiley \& Sons, New York

Harlin MM, Lindbergh JM (1977) Selection of substrata by seaweeds: optimal surface relief. Mar Biol 40:33-40

Harris LG, Ebeling AW, Laur DR, Rowley RJ (1984) Community recovery after storm damage: a case of facilitation in primary succession. Science 224:1336-1338

Heck KL, Wetstone GS (1977) Habitat complexity and invertebrate species richness and abundance in tropical seagrass meadows. J Biogeogr 4:135-142

> Himmelman JH, Cardinal A, Bourget E (1983) Community development following removal of urchins, Strongylocentrotus droebachiensis, from the rocky subtidal zone of the St. Lawrence estuary, eastern Canada. Oecologia 59: $27-39$

Hurlbert SH (1984) Pseudoreplication and the design of ecological field experiments. Ecol Monogr 54:187-211

Jenkins SR, Hawkins SJ, Norton TA (1999) Direct and indirect effects of a macroalgal canopy and limpet grazing in structuring a sheltered inter-tidal community. Mar Ecol Prog Ser 188:81-92

Jenkins SR, Coleman RA, Della Santina P, Hawkins SJ, Burrows MT, Hartnoll RG (2005) Regional scale differences in the determinism of grazing effects in the rocky intertidal. Mar Ecol Prog Ser 287:77-86

Johnson CR, Mann KH (1988) Diversity, patterns of adaptation, and stability of Nova Scotian kelp beds. Ecol Monogr 58:129-154

- Kim JH (1997) The role of herbivory, and direct and indirect interactions, in algal succession. J Exp Mar Biol Ecol 217: $119-135$

Lauzon-Guay JS, Scheibling RE (2007) Behaviour of sea urchin (Strongylocentrotus droebachiensis) grazing fronts: food-mediated aggregation and density-dependent facilitation. Mar Ecol Prog Ser 329:191-204

Lauzon-Guay JS, Scheibling RE, Barbeau MA (2009) Modelling phase shifts in a rocky subtidal ecosystem. Mar Ecol Prog Ser 375:25-39

Lieberman M, John DM, Lieberman D (1979) Ecology of subtidal algae on seasonally devastated cobble substrates off Ghana. Ecology 60:1151-1161

- Lieberman M, John DM, Lieberman D (1984) Factors influencing algal species assemblages on reef and cobble substrata of Ghana. J Exp Mar Biol Ecol 75:129-143

Lubchenco J (1978) Plant species diversity in a marine intertidal community: importance of herbivore food preference and algal competitive abilities. Am Nat 112:23-39

Lubchenco J (1980) Algal zonation in the New England rocky intertidal community: an experimental analysis. Ecology 61:333-344

Lubchenco J (1983) Littornia and Fucus: effects of herbivores, substratum heterogeneity, and plant escapes during succession. Ecology 64:1116-1123

Lubchenco J, Gaines S (1981) A unified approach to marine plant-herbivore interactions. I. Populations and communities. Annu Rev Ecol Syst 12:405-437

Lubchenco J, Menge BA (1978) Community development and persistence in a low rocky intertidal zone. Ecol Monogr 48:67-94

McCook LJ, Chapman ARO (1991) Community succession following massive ice-scour on an exposed rocky shore: effects of Fucus canopy algae and of mussels during late succession. J Exp Mar Biol Ecol 154:137-169

McCook LJ, Chapman ARO (1997) Patterns and variations in natural succession following massive ice-scour of a rocky intertidal seashore. J Exp Mar Biol Ecol 214:121-147

> Menge BA, Lubchenco J (1981) Community organization in temperate and tropical rocky intertidal habitats: prey refuges in relation to consumer pressure gradients. Ecol Monogr 51:429-450

> Menge BA, Lubchenco J, Ashkenas LR (1985) Diversity, heterogeneity and consumer pressure in a tropical rocky intertidal community. Oecologia 65:394-405

Miller R (1985) Succession in sea urchin and seaweed abundance in Nova Scotia, Canada. Mar Biol 84:275-286

> Osman RW (1977) The establishment and development of a marine epifaunal community. Ecol Monogr 47:37-63

> Paine RT (2002) Trophic control of production in a rocky intertidal community. Science 296:736-739

Paine RT, Vadas RL (1969) The effects of grazing by sea urchins, Strongylocentrotus spp., on benthic algal populations. Limnol Oceanogr 14:710-719

Petraitis PS (1987) Factors organizing rocky intertidal communities of New England: herbivory and predation in sheltered bays. J Exp Mar Biol Ecol 109:117-136

Petraitis PS (1990) Direct and indirect effects of predation, herbivory and surface rugosity on mussel recruitment. Oecologia 83:405-413

Robson BJ (1996) Habitat architecture and trophic interaction strength in a river: riffle-scale effects. Oecologia 107: 411-420

Russell BD, Connell SD (2005) A novel interaction between nutrients and grazers alters relative dominance of marine habitats. Mar Ecol Prog Ser 289:5-11

Scheibling RE (1984) Echinoids, epizootics and ecological stability in the rocky subtidal off Nova Scotia, Canada. Helgol Mar Res 37:233-242

> Scheibling R (1986) Increased macroalgal abundance following mass mortalities of sea urchins (Strongylocentrotus droebachiensis) along the Atlantic coast of Nova Scotia. Oecologia 68:186-198

> Scheibling RE, Hamm J (1991) Interactions between sea urchins (Strongylocentrotus droebachiensis) and their predators in field and laboratory experiments. Mar Biol 110:105-116

Scheibling RE, Raymond BG (1990) Community dynamics on a subtidal cobble bed following mass mortalities of sea urchins. Mar Ecol Prog Ser 63:127-145

Scheibling RE, Robinson MC (2008) Settlement behaviour and early post-settlement predation of the sea urchin Strongylocentrotus droebachiensis. J Exp Mar Biol Ecol 365:59-66

Scheibling RE, Stephenson RL (1984) Mass mortality of Strongylocentrotus droebachiensis (Echinodermata: Echinoidea) off Nova Scotia, Canada. Mar Biol 78:153-164

Scheibling RE, Hennigar AW, Balch T (1999) Destructive grazing, epiphytism, and disease: the dynamics of sea urchin-kelp interactions in Nova Scotia. Can J Fish Aquat Sci 56:2300-2314

Scheibling RE, Kelly NE, Raymond BG (2008) Physical disturbance and community organization on a subtidal cobble bed. J Exp Mar Biol Ecol 368:99-100

Smith F, Witman JD (1999) Species diversity in subtidal landscapes: maintenance by physical processes and larval recruitment. Ecology 80:51-69

- Steneck RS (1982) A limpet-coralline alga association: adaptations and defenses between a selective herbivore and its prey. Ecology 63:507-522

Steneck RS (1986) The ecology of coralline algal crusts: convergent patterns and adaptive strategies. Annu Rev Ecol Syst 17:273-303 
Steneck RS, Watling L (1982) Feeding capabilities and limitation of herbivorous molluscs: a functional group approach. Mar Biol 68:299-319

Turner T (1983) Facilitation as a successional mechanism in a rocky intertidal community. Am Nat 121:729-738

> Underwood AJ, Denley EJ, Moran MJ (1983) Experimental analyses of the structure and dynamics of mid-shore rocky intertidal communities in New South Wales. Oecologia 56: 202-219

Vanderklift MA, Kendrick GA (2004) Variation in abundances of herbivorous invertebrates in temperate reef habitats. Mar Freshw Res 55:93-103

Editorial responsibility: Morten Pedersen, Roskilde, Denmark
Wentworth CK (1922) A scale of grade and class terms for clastic sediments. J Geol 30:377-393

Williams GA, Davies MS, Nagarkar S (2000) Primary succession on a seasonal tropical rocky shore: the relative roles of spatial heterogeneity and herbivory. Mar Ecol Prog Ser 203:81-94

Witman JD (1985) Refuges, biological disturbance, and rocky subtidal community structure in New England. Ecol Monogr 55:421-445

Worcester SE (1995) Effects of eelgrass beds on advection and turbulent mixing in low current and low shoot density environments. Mar Ecol Prog Ser 126:223-232

Submitted: August 11, 2008; Accepted: February 11, 2009

Proofs received from author(s): April 10, 2009 